\title{
BSA - loaded gelatin microspheres: \\ Comparative studies on biodegradation and drug release in presence of collagenase and trypsin
}

\author{
Kristina Mladenovska1 $^{*}$, Emilija Janevic ${ }^{2}$, Marija Glavas-Dodov, \\ Renata Slavevska-Raicki ${ }^{1}$, Maja Simonoska ${ }^{1}$, Katerina Goracinova ${ }^{1}$ \\ IInstitute of Pharmaceutical Technology, Faculty of Pharmacy, University "Ss. Cyril and Methodius", \\ Vodnjanska 17, 1000 Skopje, Republic of Macedonia \\ 2Institute of Pathophysiology and Nuclear Medicine, Faculty of Medicine, University "Ss. Cyril and Methodius", \\ Vodnjanska 17, 1000 Skopje, Republic of Macedonia
}

Received June 2003; accepted August 2003

\begin{abstract}
Certain variations in the process parameters (emulsification time, surfactant concentration) were performed in order to prepare BSA-loaded gelatin microspheres with particle size ranging from 1 to $10 \mu \mathrm{m}$ and high loading efficiency using a procedure originally employed by Tabata and Ikada. In vitro degradation and drug release studies in the presence of trypsin and collagenase, respectively, were performed in order to evaluate the potential of gelatin microspheres as regulated and sustained release systems for oral vaccination. Degradation data showed that the preparation procedure had provided prolonged degradation in the presence of both enzymes, suggesting complete in vivo degradation. Exponential dependence of the amount of drug released on time was evidenced. The diffusion coefficients were superior to 0.5 indicating the Case II anomalous Fickian diffusion, except for the particles smaller than $5 \mu \mathrm{m}$ where in the presence of collagenase the transition to Super Case II transport was observed due to the higher rate of polymer degradation and BSA diffusion through the matrix. The mathematical modeling of drug release showed a biphasic release pattern in the presence of both enzymes, where the rate constants for the initial time release confirmed the influence of the particle size and/or enzymatic degradation rate on the drug release rate.
\end{abstract}

Key words: Gelatin microparticles, BSA, controlled release, trypsin, collagenase

\section{Introduction}

There is a body evidence which suggests that the absorption of orally administered antigen in the intestines stimulate particular cells in the gut-associated lymphoid tissue (GALT), especially in the Peyer's patches (PP) leading to dissemination of $\mathrm{B}$ and $\mathrm{T}$ cells to mucosal effector tissues for subsequent antigen-specific secretory IgA responses. A number of potential delivery systems, including sustained-antigen releasing polymer based microparticulated carriers have been used for targeting the PP and protecting the antigen of interest from the harsh environment of the GIT (1-2). Among the natural polymers forming the particles, gelatin is known for its excellent bio-

\footnotetext{
* kmladenovska@baba.ff.ukim.edu.mk

Phone:+389 02126 032; 119 694; Fax: +389 02123054
}

compatibility due to low toxicity and poor immunogenic reaction (3). Furthermore, gelatin microspheres proved to evoke the immune response at the genito-urinary mucosa, suggesting the possibility to develop an oral vaccine (4). The strong adjuvant effect is considered to be derived from, at first, their function as carriers in the GIT to deliver antigens to the immuno-inductive site (PP), protecting them from enzymatic degradation. Gelatin microspheres taken up by PP gradually release the antigens, which are then recognized as infectious substances by B cells in the GALT. It is also possible to consider that the function of gelatin itself as an accelerator of macrophagocytosis might relate to the strong adjuvant effect of gelatin microspheres.

Variations in particle size can control particle uptake into mucosa subepithelial regions, while the control of mechanical characteristics as well as degradation kinetics 
via gelatin cross-linking could be achieved (5-6). The treatment of gelatin by glutarldehyde (GTA) gives rise to the formation of scarcely or non-soluble products which can slow down the release of the encapsulated drug. Cross-linking is optimal at neutral $\mathrm{pH}$ and requires free non-protonated $\varepsilon$-amino groups of lysine and hydroxylysine to form imines. GTA reacts not only with amino groups, but with carboxylic, amide and other groups of proteins, as well. Additional polymerization by aldol condensation results in covalent intramolecular cross-links connecting distant gelatin molecules.

Gelatin degradation by all cell types can occur either after phagocytosis or by extracellular protease acting at either neutral or acid $\mathrm{pH}$. At neutral $\mathrm{pH}$ only specific collagenases simply attacks the Gly-X-Y sequence and are capable of cleaving the triple helix at multiple sites. Collagenase binds tightly to triple-helices at or near surface, whereas molecules in the interior become accessible to enzymes in the course of the progressive degradation from the outside (6). After the triple-helix is cracked, further degradation is facilitated by enzymes such as gelatinases and non-specific proteinases that cleave the primary fragments into small peptides and amino acids. Comparing to other neutral proteinases, trypsin appeared the most specific enzyme for gelatin microparticle degradation (7).

BSA-loaded gelatin microspheres were prepared by emulsification of aqueous solution of gelatin and BSA, into the particles in an oil (8-9). FTIR-ATR spectroscopic studies have confirmed that, during the preparation process and freeze-drying procedure, only minor conformational changes of protein ( $\alpha$-helix and $\beta$-sheet content) were induced, owing to the effective preservation provided by the presence of sorbitol (10-11). Variations in the formulation and process parameters were performed in order to prepare microspheres with high loading efficiency and an optimal size for uptake into subepithelial mucosa 1-10 $\mu \mathrm{m}$. It was previously shown that microspheres with diameter from 5 to $10 \mu \mathrm{m}$ remained in the PP, where they induced mucosal immunity, whereas the microspheres smaller than $5 \mu \mathrm{m}$ in diameter passed through the PP within macrophages to stimulate systemic immunity $(2,12-13)$. "Model" protein, BSA, facilitated the understanding of the release kinetics. A key parameter appeared to be the particle size, so the correlation between the biodegradation and drug release rates in the presence of collagenase and trypsin, respectively and drug and polymer particle size was established as an object of this research.

\section{Materials and Methods}

\section{Materials}

Gelatin was purchased from Merck (Germany), bovine serum albumin, glutaraldehyde and sorbitan monooleate (SPAN $80^{\circledR}$ ) from Sigma Chemical Co. (Germany), while sorbitol from Merck (Germany). Radiolabelling of BSA was performed by ${ }^{131} \mathrm{I}$ obtained from Biointernational (France). Collagenase (EC 3.4.24.3.) from Clostridium histoliticium lyophilised and Trypsin, EC 3.4.21.4. were kindly donated by Varus (Representative office of Merck, Germany for Macedonia).

\section{Preparation of microspheres}

The microspheres were prepared by emulsification of aqueous solution of gelatin and radiolabelled ${ }^{131} \mathrm{I}$-BSA into the particles in an organic phase (9). In short, $0.2 \mathrm{ml}$ gelatin aqueous solution $(10 \mathrm{w} / \mathrm{v} \%)$ with $5 \mathrm{mg}$ BSA $(2.5$ $w / v \%$ in feed) was emulsified in a mixture of toluolum and chloroform (1:1) containing sorbitan monooleate (SPAN 80) in adequate concentration. The resulting emulsion was quickly poured into precooled mixture of toluolum and chloroform (1:3) containing $5 \% \mathrm{~m} / V$ SPAN 80. The gelatin was cross-linked with GTA-saturated toluene $\left(0.05 \mathrm{mg} \mathrm{mg}^{-1}\right.$ gelatin $)$ in the emulsion at $0^{\circ} \mathrm{C}$ for 4 hours. The resulting microspheres were successively washed with isopropanol, purified water, and then freezedried at $200 \mathrm{~Pa}$ and $-40{ }^{\circ} \mathrm{C}$ (Christ $\alpha$ 2-4, Bioblock, Scientific, France) in the presence of sorbitol as a lyoprotectant of protein structure. Variations in the formulation and process parameters, surfactant concentration and time of emulsification (Table 1) were performed in order to prepare microspheres with high microencapsulation efficacy and size ranging from 1 to $10 \mu \mathrm{m}$.

Table 1. Formulation and process variables of gelatin microsheres

\begin{tabular}{|c|c|c|}
\hline $\begin{array}{c}\text { Type of } \\
\text { microspheres }\end{array}$ & $\begin{array}{c}\text { SPAN } 80 \\
\text { concentration in } \\
\text { emulsion, w/v\% }\end{array}$ & $\begin{array}{c}\text { Time of } \\
\text { emulsification, } \\
\text { minutes }\end{array}$ \\
\hline A & 5 & \\
\hline A-1 & & 15 \\
\hline A-2 & & 30 \\
\hline A-3 & & 45 \\
\hline B & 8 & \\
\hline B-1 & & 15 \\
\hline B-2 & & 30 \\
\hline B-3 & & 45 \\
\hline $\mathrm{C}$ & 10 & \\
\hline C-1 & & 15 \\
\hline C-2 & & 30 \\
\hline C-3 & & 45 \\
\hline $\mathrm{D}$ & 12 & \\
\hline D-1 & & 15 \\
\hline D-2 & & 30 \\
\hline D-3 & & 45 \\
\hline
\end{tabular}




\section{Microspheres size measurement}

The mean diameter of the population of gelatin microspheres in aqueous dispersions was determined using laser diffractometry (Particle size analysette D LAB/22, Fritsh, Germany). The spherical form was based on optical micrographs of gelatin microspheres (camera Nikon E-800, Japan) using technique of phase contrast.

\section{Determination of drug loading}

The content of radiolabelled ${ }^{131} \mathrm{I}$-BSA entrapped in gelatin matrix was calculated as a percent of total radioactivity present in the supernatant and in the filtrate after microsphere isolation ("well" counter Scaler Type N 529 D, EKCO Electronics, UK).

\section{In vitro degradation of gelatin microspheres}

In vitro degradation in the presence of collagenase. Gelatin microspheres $\left(0.5 \mathrm{mg} \mathrm{m}^{-1}\right)$ were suspended in calcium $\left(0.05 \mathrm{mg} \mathrm{ml}^{-1} \mathrm{CaCl}_{2}\right)$ containing PBS with collagenase $\left(0.5 \mathrm{mg} \mathrm{ml}^{-1}\right)$. In vivo conditions $\left(37^{\circ} \mathrm{C}, 75 \mathrm{Str}^{\mathrm{min}}{ }^{-1}\right)$ were simulated in a horizontal shaker (Haake SWB 20, Fisons, Germany). At regular time intervals, the dispersion was centrifuged at $8000 \mathrm{rpm}$ for $15 \mathrm{~min}$ (Jouan MR 22i Centrifuge, France) and the amount of gelatin in the sediment was determined according to a ninhydrin method (14).

In vitro degradation in a presence of trypsin. Aqueous dispersion of microspheres $\left(1.5 \mathrm{mg} \mathrm{ml}^{-1}\right)$ was used to determine in vitro enzymatic degradation rate in the presence of trypsin $\left(0.4 \mathrm{mg} \mathrm{ml}^{-1}\right)$ according to the method proposed by Roser and Kissel (7). Turbidity was measured at the beginning and during regular time intervals by the absorbance at $546 \mathrm{~nm}$ (UV/VIS Lambda 16, Perkin Elmer Spectrophotometer, USA).

\section{In vitro release of BSA from gelatin microspheres}

The amount of BSA released from gelatin microspheres in the presence of collagenase and trypsin, respectively, was determined by measuring the radioactivity present in the supernatants in regular time intervals. To simplify the analysis of controlled release data, the empirical, exponential equation was used (11):

$$
M t / M_{o}=k t^{n}
$$

where $M_{t} / M_{o}$ is the fraction of drug released; $\mathrm{t}$ is the release time, $n$ is a diffusional exponent characteristic of the release mechanism, and $k$ denotes properties of the polymer and the drug. This equation applies until $60 \%$ of the total amount of drug is released. It predicts that the fractional release of drug is exponentially related to the release time and it adequately describes the release of drug from swellable and non-swellable polymer devices of varying geometry. For swellable controlled release systems, the slope (n) of the log (drug released) vs. log (time) plot is 0.45 for pure Fickian diffusion. An anomalous non-Fickian diffusion pattern (0.45-0.89) is observed when the rates of the solvent penetration and drug release are in the same transport $(\mathrm{n}>1)$ is observed when drug diffusion is rapid compared to the constant rate of solvent induced relaxation and swelling in the polymer (15-17). In order to determin the initial and late time drug release rate, the in vitro release profiles from microspheres were described using biexponential function: $\mathrm{M}_{\propto}-\mathrm{M}_{\mathrm{t}} / \mathrm{M}_{\propto}=\mathrm{Ae}^{-\alpha \mathrm{t}}+\mathrm{Be}-\beta \mathrm{t}$, where $\alpha$ and $\beta$ are the rate constants for the initial and late time releases (18).

\section{Results and Discussion}

\section{Effect of formulation and procedure parameters on microspheres size and loading efficacy}

The mean diameter of microspheres prepared in this study was in the range from $1.20( \pm 1.96)$ to $7.03( \pm 1.23)$ $\mu \mathrm{m}$, which is in the frame of optimal size for uptake into GALT and systemic immunoresponsive organs. By extending the time of emulsification and increasing the surfactant concentration, particle size decreased in all series of the gelatin microspheres. Two-factorial analysis of variance $(\alpha=0.05)$ confirmed that the time of emulsification dominantly influenced the microspheres size at all surfactant concentrations.

During the preparation procedure, due to the many functional groups BSA could be entrapped in the gelatin matrix not through the cross-linking reaction, only, but also by non-covalent bonding forces. High percentage of encapsulation is an important parameter to be considered in order to reduce the amount of administered microspheres to obtain in vivo activity. Considering the drug loading data, a very high percentage of encapsulation was achieved; from 80 to $95 \%$ (Fig. 1).

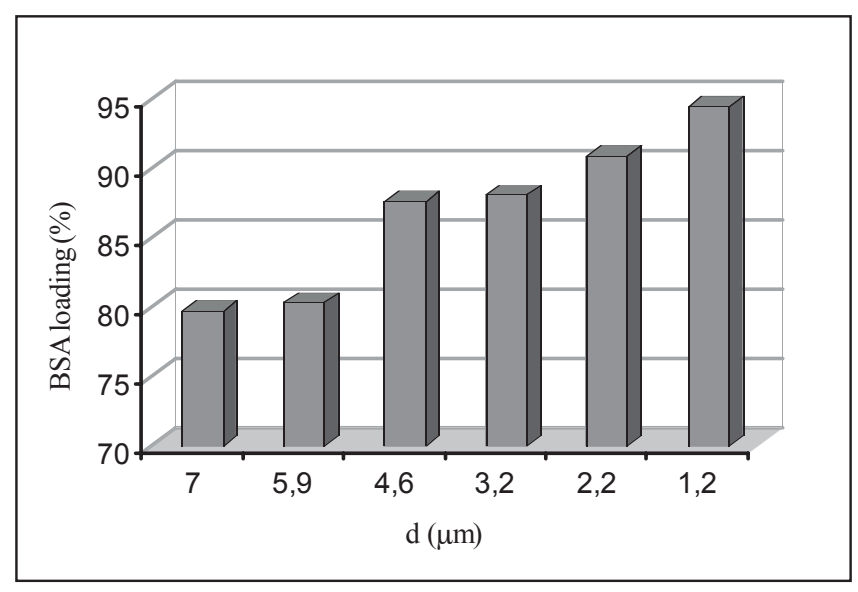

Fig. 1. BSA loading of gelatin microspheres (\%) as a function of mean particle diameter;7.0 $\mu \mathrm{m}$ (A-1); $5.9 \mu \mathrm{m}$ (B-1); $4.6 \mu \mathrm{m}$ (D-1); $3.2 \mu \mathrm{m}$ (A-2); $2.2 \mu \mathrm{m}$ (C-2); $1.2 \mu \mathrm{m}$ (D-3) 


\section{In vitro biodegradation studies of gelatin microspheres}

Degradation data of gelatin microspheres in the presence of both enzymes showed that the GTA cross-linking degree, as well as additional cross-linking due to the freeze-drying procedure provided prolonged enzymatic degradation in all series of gelatin microspheres, suggesting complete in vivo degradation. For e.g., during $72 \mathrm{~h}$ at $37^{\circ} \mathrm{C}$ between 84 and $90 \%$ of gelatin microspheres were degraded in the presence of collagenase (Fig. 2a). Similarly, between 80 and $91 \%$ of microspheres were degraded during $96 \mathrm{~h}$ in the presence of trypsin (Fig. 2b). The difference in the degradation rate between the two enzymes suggests a degree of enzyme specificity. These results are in agreement with the data reported in the literature for collagen nanoparticles (19) and for gelatin nanoparticles where comparing to protease and $\alpha$-chymotrypsin, trypsin appears to be the most suitable enzyme for gelatin nanoparticle degradation (7). The statistical analysis confirmed statistically significant difference at $\alpha=.05$ in degradation rate among the series with different particle size in the presence of both enzymes.

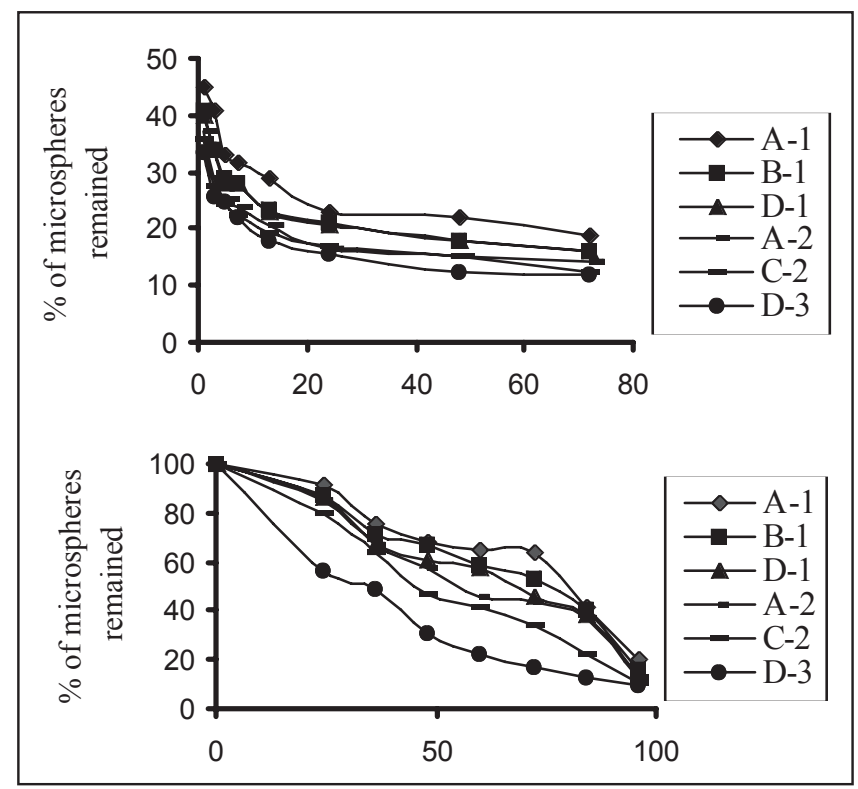

Fig. 2. Degradation profiles of gelatin microspheres in the presence of collagenase (a) and trypsin (b); particle size between $7.03 \mu \mathrm{m}(\mathrm{A}-1)$ and $1.20 \mu \mathrm{m}(\mathrm{D}-3)$

\section{In vitro release studies}

In all series of gelatin microspheres, regardless the enzyme present, the BSA release profiles showed a biphasic modulation characterized by an initial relatively rapid release, followed by a continuous much slower release that decreased progressively until complete release of BSA. If such a release profile is reproduced in vivo, the drug effect will be obtained in a relatively short period to obtain therapeutic effect and the slow release period will serve to maintain this effect.
The BSA release followed the swelling behavior and enzymatic erosion of gelatin microspheres. Thus, the release kinetics was determined not only by the rate of enzymatic degradation, but also by the rate of water uptake and the rate of drug dissolution, associated with the movements of the swelling front, erosion front and diffusion front. Concerning the last one, termed also as undissolved drug front it should be emphasized that it is a function of drug solubility and loading. In addition, $\mathrm{C}-\mathrm{C}$ bonds of cross-linked natural polymers, such as gelatin, are characterized with relatively high capability to overcome the potential energetic barrier for rotating when the polymer is in a rubbery state. Such freedom results in a series of changes in flexibility and conformation of polymer chains that influence on the drug liberation. Whereas interaction between water, polymer and drug are the primary factors for release control, various formulation parameters, such as polymer grade, drug/polymer ratio and drug and polymer particle size can influence on the drug release rate to greater or lesser degree, also. Concerning all these parameters strictly linked to the drug release kinetics, the differences in BSA release rate were observed in the series of gelatin microspheres with different particle size, and also, between the series of gelatin microspheres treated with both enzymes, separately.

"Lag" phase of very low release was observed during the first hours of the study (1-3 h) depending on particle size and enzyme present. Namely, during the $1^{\text {st }}$ hour of the study between 5 and $10 \%$, of BSA were released in a presence of collagenase, while the same amount of BSA was released in a period of $3 \mathrm{~h}$ when trypsin was present. The time necessary for the dissolution medium to penetrate into the gelatin matrix and enzymatic complex with the polymeric particles to be formed can explain the delayed initial release of BSA, while the low release in a "lag" phase can be explained by the release of poorly entrapped and surface associated BSA.

The initial release of BSA was between 80 and $93 \%$ in a period of $24 \mathrm{~h}$ in the presence of collagenase, while in the same initial period nearly 67 to $85 \%$ of the entrapped BSA was released from gelatin microspheres treated with trypsin. At the same, in vitro conditions the faster water penetration into the spheres supported by the faster enzymatic degradation and thus, more free drug liberation resulted in a higher percent initially released in the series of gelatin microspheres with lower mean diameter. On contrary, increase in particle size decreased the biodegradation rate and increased the polymer relaxation time resulting in an extended duration of drug release. So, the high correlation between the particle size and the drug release rate in presence of both enzymes was observed. 
Namely, in the series of gelatin microspheres with mean diameter smaller than $4 \mu \mathrm{m}$, between 40 and $55 \%$ of total drug was released during $3 \mathrm{~h}$ in the presence of collagenase. The same percent of total drug $(\sim 37 \%)$ in the series of gelatin microspheres with mean diameter higher than $4 \mu \mathrm{m}$ was $\sim 6 \mathrm{~h}$ (Fig. 3a). Similarly, in the presence of trypsin during $9 \mathrm{~h}$ between 40 and $80 \%$ of BSA were released from particles with mean diameter between 7.03 $\mu \mathrm{m}$ and $1.20 \mu \mathrm{m}$ (Fig. 3b). These data are in correlation with degradation data in which trypsin and collagenase showed different degree of specificity. Namely, it is well known that the action of trypsin is restricted to peptide links involving the carboxylic groups of lysine and arginine. The hydrolytic reaction is slowed down when $\varepsilon$-amino groups of lysine residues are substituted; the splitting action being restricted to arginyl bonds (7).

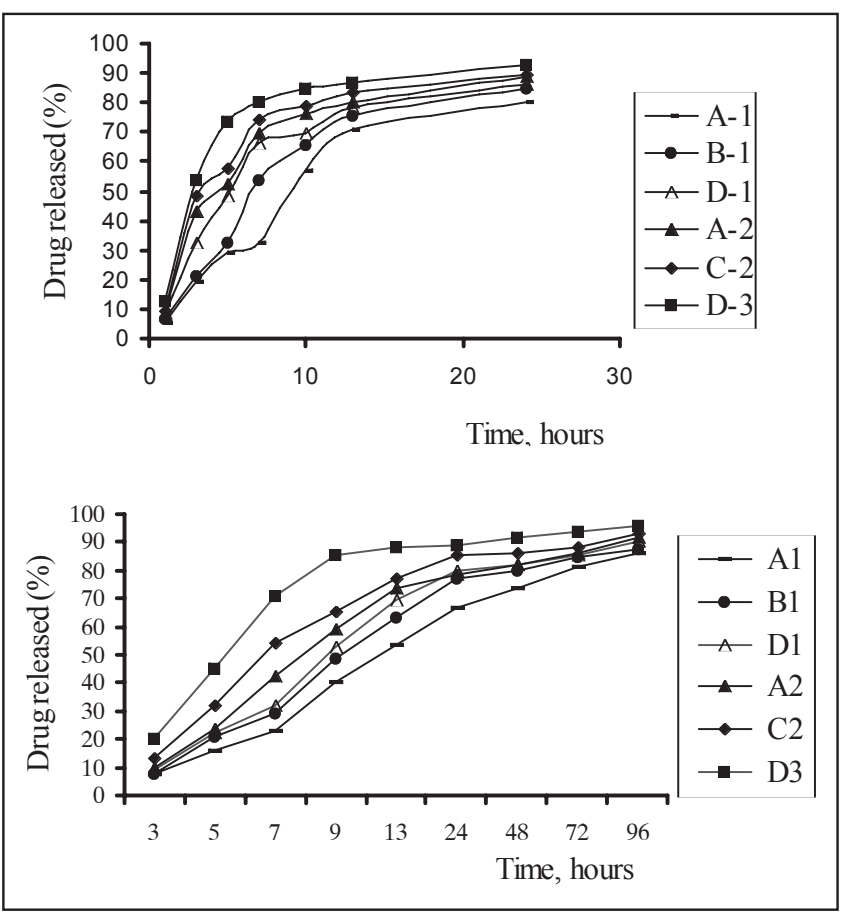

Fig. 3. BSA released (\%) from gelatin microspheres in the presence of collagenase (a) and trypsin (b); particle size between $7.03 \mu \mathrm{m}(\mathrm{A}-1)$ and $1.20 \mu \mathrm{m}(\mathrm{D}-3)$
Table 2. Exponential dependence of the amount of BSA released on time

\begin{tabular}{ccccc}
\hline $\begin{array}{c}\text { Series of gelatin } \\
\text { microspheres d, } \mu \mathrm{m}\end{array}$ & \multicolumn{2}{c}{$\begin{array}{c}\text { Microspheres treated } \\
\text { with collagenase }\end{array}$} & \multicolumn{2}{c}{$\begin{array}{c}\text { Microspheres } \\
\text { treated with } \\
\text { trypsin }\end{array}$} \\
\hline & $\mathrm{n}$ & $\mathrm{r}$ & $\mathrm{n}$ & $\mathrm{r}$ \\
\hline A-1 (7.03) & 0.99 & 0.991 & 1.02 & 0.987 \\
B-1 (5.89) & 1.05 & 0.997 & 1.04 & 0.975 \\
D-1 (4.63) & 1.17 & 0.990 & 1.03 & 0.962 \\
A-2 (3.20) & 1.15 & 0.994 & 1.04 & 0.962 \\
C-2 (2.19) & 1.18 & 0.980 & 0.79 & 0.978 \\
D-3 (1.20) & 1.33 & 1.000 & 0.58 & 1.000 \\
\hline
\end{tabular}

Exponential dependence of the amount of BSA release on time was evidenced; the diffusion exponents in the presence of trypsin were superior to 0.45 (0.58-1.04) indicating the influence of polymer relaxation and diffusion through the matrix in BSA release. Considering the exponential dependence of BSA released on time in the presence of collagenas was observed indicating complete water penetration into the spheres supported by the faster enzymatic degradation and thus, more free drug liberation (Table 2).

Literature data $(14,17)$ confirmed that such a biphasic modulation of drug release is typical for swellable polymer matrices regardless their shape, particle size and drug loading. Considering this, the constants for the initial $(\alpha)$ and late time release $(\beta)$ were determined using biexponential function that includes degradation, swelling and diffusion rate (Table 3).

\section{Conclusion}

With the aim of obtaining cross-linked gelatin-based microparticles as potential adjuvant in oral immunization the resistance to enzymatic degradation and control of drug release rate in the presence of collagenase and trypsin was evaluated. The diffusional exponents $(n)$ according to the general exponential release equation indicate anomalous (non-Fickian) and Case-II transport mechanism in BSA release from swellable gelatin ma-

Table 3. Rate constants for the initial $(\alpha)$ and late time releases $(\beta)$ according to the biexponential function

\begin{tabular}{|c|c|c|c|c|c|c|c|c|}
\hline \multirow{3}{*}{$\begin{array}{l}\text { Series of gelatin } \\
\text { microspheresd, } \mu \mathrm{m}\end{array}$} & \multicolumn{8}{|c|}{ Kinetic parameters according to biexponential function } \\
\hline & \multicolumn{4}{|c|}{ Microspheres treated with collagenase } & \multicolumn{4}{|c|}{ Microspheres treated with trypsin } \\
\hline & $\mathrm{r}_{1}$ & $\alpha, \mathrm{h}^{-1}$ & $\mathrm{r}_{2}$ & $\beta, \mathrm{h}^{-1}$ & $\mathrm{r}_{1}$ & $\alpha, h^{-1}$ & $\mathrm{r}_{2}$ & $\beta, h^{-1}$ \\
\hline A-1 (7.03) & 0.977 & 0.058 & 0.930 & 0.066 & 0.967 & 0.050 & 0.997 & 0.012 \\
\hline B-1 (5.89) & 0.999 & 0.081 & 0.957 & 0.071 & 0.986 & 0.094 & 0.948 & 0.012 \\
\hline D-1 (4.63) & 1.000 & 0.151 & 0.998 & 0.072 & 0.991 & 0.114 & 0.966 & 0.012 \\
\hline $\mathrm{A}-2(3.20)$ & 1.000 & 0.155 & 0.948 & 0.072 & 0.997 & 0.129 & 0.981 & 0.012 \\
\hline C-2 (2.19) & 1.000 & 0.248 & 0.963 & 0.074 & 0.988 & 0.136 & 0.937 & 0.012 \\
\hline D-3 (1.20) & 1.000 & 0.321 & 0.938 & 0.078 & 0.999 & 0.289 & 0.989 & 0.013 \\
\hline
\end{tabular}


trices. At the same cross-linking degree, the particle size has an impact on the drug release rate through the polymer relaxation time, diffusive processes and degradation rate. The difference in enzymatic specificity in degradation rate reflects the BSA release, so the higher release rates in the presence of collagenase were observed. The faster water uptake into the spheres supported by the faster enzymatic degradation in the presence of collagenase resulted in more free drug liberation in the series of gelatin microspheres with lower mean diameter where a transition toward Super-Case II transport in BSA release was observed.

\section{References}

1. H.O. Alpar, K.R. Ward and E.D. Williamson, S. T. P. Pharma. Sci., 10 (4) 269-78 (2000).

2 S. Trolle, A. Andremont and E. Fattal, S.T.P. Pharma. Sci., 8 (1), 19-30 (1998).

3. C. Weber, C. Coester, J. Kreuter and K. Langer, Int. J. Pharm., 194 (1), 91-102 (2000).

4. M. Nakamura, S. Yamashita, Y. Tsume, T. Nadai, H. Sezaki, T. Kohno, Y. Tabata and Y. Ikada, S.T.P. Pharma. Sci 8., (1), 67-73 (1998).

5. R. Cortesi, E. Esposito, M. Osti, G. Squarzoni, E. Menegatti, S. S. Davis and C. Nastruzzi, Eur. J. Pharm. Biopharm., 47 (2), 153-60 (1999).
6. F. Friess, Eur. J. Pharm. Biopharm., 45 (2), 113-36 (1998).

7. E. Leo, M. A. Vandelli, R. Cameroni and F. Forni, Int. J. Pharm., 155 (2), 75-82 (1997).

8. J. Kreuter, Colloidal drug delivery systems, Marcel Dekker, Inc., 1994, pp 219-342.

9. Y. Tabata and Y. Ikada, Pharm Res 6 (2), 422-27 (1994).

10. K. Griebenow, A. M. Santos and K. G. Carrasquillo, The Internet J Vibrational Spectroscopy, Vol. 3, 1st Ed. (1999).

11. K. Mladenovska, Lj. Klisarova, E. I. Janevik and K. Goracinova, Acta Pharm 52 (2), 91-100 (2002).

12. H. O. Alpar, J. E. Eyles and E. D. Wiliamson, S.T.P. Pharma. Sci., 8 (1), 31-9 (1998).

13. K. Mladenovska, E. I. Janevik, M. D. Glavas, E. F. Kumbaradzi and K. Goracinova, Int. J. Pharm., 242 (1-2), 247-49 (2002).

14. E. Sawicki, T. R. Hanser, T. W. Stanley and W. Elbert, Anal. Chem., 33 (3), 93-6 (1961).

15. F. A. Radu, M. Bause, P. Knabner, L. W. Geoffrey and W. C. Friess, J. Pharm. Sci., 91 (4), 964-72 (2002).

16. C. S. Brazel and N. A. Peppas, Eur. J. Pharm., Biopharm., 49 (2), 47-58 (2000).

17. Y. Tabata and Y. Ikada, Adv. Drug. Deliv. Rew., 31 (2), 287-301 (1998).

18. M. I. Ugwoke, N. Verbeke and R. Kinget, Int. J. Pharm., 148 (2), 23-32 (1997).

19. M. El Samaligy and P. Rohdewald, J. Pharm. Pharmacol., 35 (3), 537-39 (1983).

\title{
Резиме
}

\section{Желатинските микросфери како потенцијални носачи на антигени: компаративни испитувања на брзината на деградација и ослободување во присуство на колагеназа и трипсин}

\author{
Кристина Младеновска1*, Емилија Јаневиќ ${ }^{2}$, Марија Главаш-Додов ${ }^{1}$,

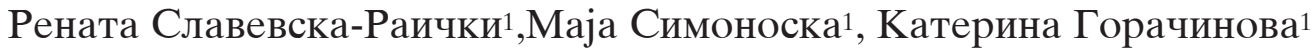

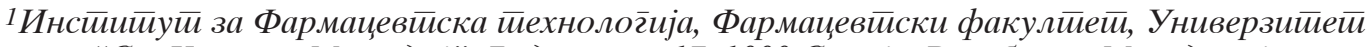 \\ “Св. Кирил и Мейодиј”, Водњанска 17, 1000 Скойје, Рейублика Македонија

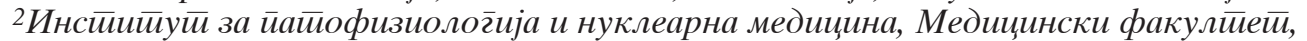

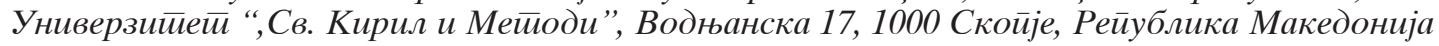

Клучни зборови: желатински микросфери, албумин, контролирано ослободување, колагеназа, трипсин

Подготвени се желатински микросфери во кои е инкорпориран албумин со користење на методот на Табата и Икада. Со варијации во производните и во формулациските параметри подготвени се честички со висока ефикасност на инкорпорирање и големина помеѓу 1 и $10 \mu \mathrm{m}$. Со цел да се оцени потенцијалот на желатинските микросфери како носачи за контролирано и насочено ослободување антигени по орална примена следени се брзината на деградација и брзината на ослободување на албуминот во присуство на ензимите трипсин и колагеназа. Експоненцијалната зависност на количината на ослободен албумин во време упатува на Case II видоизменета Fick-ова дифузија, освен кај честичките со дијаметар помал од $5 \mu \mathrm{m}$ во кои во присуство на колагеназа се забележува премин кон Super Case II транспорт поради поголемата брзина на деградација и дифузија на албуминот низ матриксот. Овие резултати се во согласност со биодеградацијата на честичките, при што се забележува одредена разлика во специфичноста на дејствувањето на соодветните ензими. Математичката обработка на резултатите на ослободување на албуминот покажува бифазна модулација, при што константите за иницијалното, односно одложеното ослободување го потврдуваат влијанието на големината и/или брзината на деградација на честичките врз брзината на ослободување на албуминот. 